\title{
Occupational stress, uncertainty and organisational commitment in higher education: Job satisfaction as a moderator
}

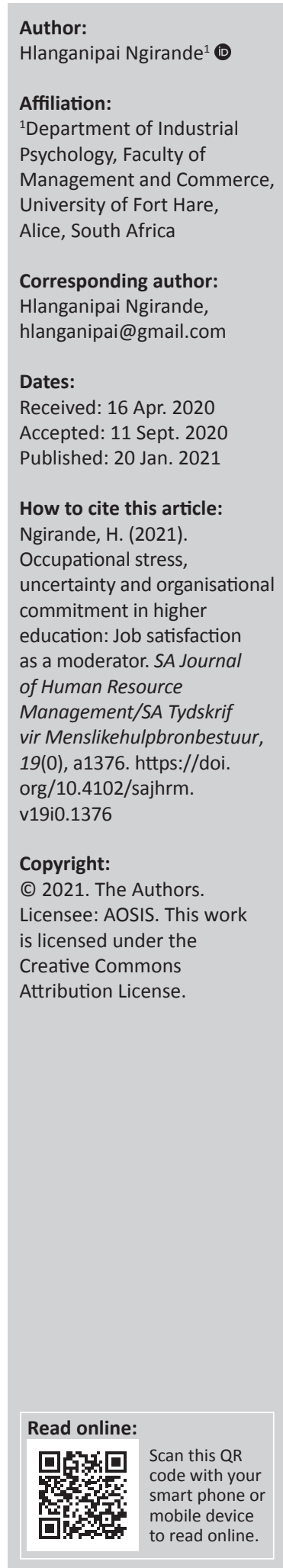

Orientation: Committed employees contribute to the success of an organisation. Therefore, organisations need to understand the level of employees' occupational stress and uncertainty to minimise their negative effects on both the individuals and the organisation. Organisations should also understand the effect of job satisfaction in explaining occupational stress and organisational commitment, as well as uncertainty and organisational commitment.

Research purpose: The purpose of the study was to investigate the relationships between occupational stress, uncertainty and organisational commitment of academic staff from two South African historically black institutions of higher learning. The study further investigated whether job satisfaction moderated the relationship between (1) occupational stress and organisational commitment and (2) uncertainty and organisational commitment.

Motivation for the study: Institutions of higher learning gain a competitive advantage by having a committed workforce. Therefore, it is necessary to investigate the drivers of organisational commitment to attain organisational success.

Research approach/design and method: A quantitative approach by using a cross-sectional survey design was used to collect data from the academic staff from two institutions of higher education $(n=424)$. Both institutions are contact institutions and are of the same level. Cronbach's alpha coefficients, factor analysis, Pearson product-moment correlation coefficient and multiple regression analyses were used to analyse the data.

Main findings: This study found a negative, significant relationship between occupational stress and organisational commitment and a negative relationship between uncertainty and organisational commitment. However, uncertainty was found to be only a significant predictor of organisational commitment. The study also found that job satisfaction moderates the relationship between uncertainty and organisational commitment. However, it does not moderate the relationship between occupational stress and organisational commitment.

Practical/managerial implications: Institutions of higher learning need to establish a conducive working climate and provide employee assistance programmes to minimise the levels of occupational stress and uncertainty and improve job satisfaction to have committed academic staff.

Contribution/value-add: The research is one of the few studies that explored the moderating role of job satisfaction with the relationship between occupational stress and organisational commitment, and the relationship between uncertainty and organisational commitment in the higher education sector. Hence, it adds new information to the body of knowledge in the sector. Institutions of higher learning can consider evaluating the levels of occupational stress, uncertainty and job satisfaction of their academic staff to promote the issue of the organisational commitment of their employees. Thus, this study has the potential to influence organisational policy on how to reduce work stress and uncertainty and improve organisational commitment.

Keywords: academic staff; confirmatory factor analysis; higher education; job satisfaction; moderator;occupational stress; organisational commitment; South Africa; uncertainty.

\section{Introduction and background}

The inception of democracy has seen the South African higher education sector undergoing a radical shift in form and identity. Increases in student diversity and access have been witnessed in the sector compared with pre-1994 (Council on Higher Education [CHE], 2013; Mawoyo, 2014; Smit, 2012). Policy documents such as the White Paper of 1997 and the South African Qualifications 
Authority (SAQA) of 1997 were introduced to redress the social injustices of the past by increasing access to higher education for all (Department of Higher Education, 1997). However, this positive paradigm shift in higher education came with its challenges.

Greater access to higher education led to higher student enrolments (De Oliveira Barbosa, Pires, \& Dwyer, 2018). For instance, in 25 years enrolment almost doubled, from 473000 in 1993 to some 800000 in 2008 (Badat, 2010). By 2016, 2 million students were enrolled in higher education, $78.3 \%$ of them in public institutions and $21.7 \%$ in private institutions (De Oliveira Barbosa et al., 2018). This massification exerted excessive pressure on already limited resources in universities, thereby affecting their success rate (Akalu, 2016; Mohamedbhai, 2014; Smit, 2012), epistemological access (Boughey, 2005; McKenna, 2012) and graduation rate (Machingambi, 2011). Various universities are under financial strain such that some have resorted to recruiting adjunct academic staff (independent contractors) rather than permanent staff to save on the wage bill (Bozzoli, 2016; Herman, 2016; Nortje, 2013). However, this cost serving mechanism may result in low organisational commitment because of high levels of occupational stress, high uncertainties about future job security and low job satisfaction among the employees regardless of one's nature of employment, which may be explained by low job satisfaction.

Zagelmeyer, Sinkovics, Sinkovics and Kusstatscher (2018) report that employees become less committed when they are stressed, when and their job security is threatened. Several studies also revealed that insecure, less satisfied and highly stressed workforce exhibits less emotional attachment to the organisation (Arnolds, Lillah, \& Stofile, 2013; Cooper, 2018; Martin \& Roodt, 2008; Öztürk, Karagonlar, \& Emirza, 2017). Therefore, for an organisation to be effective and efficient, it requires a highly committed workforce. This can be achieved when talent is managed in such a way that occupational stress and uncertainty are minimised, and job satisfaction is increased. This study argues that it is not only the organisational change that may lead to high occupational stress, uncertainty and less organisational commitment, but it is also the level of job satisfaction of an individual in an organisation following a change.

\section{Literature review Occupational stress}

Boyd, Tuckey and Winefield (2014) define stress as the individual's response to an imbalance that is perceived between the demands made in the situation and the resources available. Organisational change can lead to high occupational stress. According to Slade, Ribando and Fortner (2016), stress negatively affects employee organisational commitment. Therefore, to have committed employees, organisations should reduce the level of employee stress. The demands made on an individual (stressors) serve as a stimulus for evoking a response, such as emotions of anger, anxiety and stress (Cooper, 2018). These stressors can be internal or external. Although a single stressor may cause major stress, stressors usually combine to put pressure on an employee in a variety of ways until stress develops (Graebner, Heimeriks, Huy, \& Vaara, 2017). Hence, organisations should take note of these stressors to minimise employee occupational stress and improve organisational commitment.

\section{Uncertainty}

The significant changes introduced in the South African higher education system soon after 1994, in redressing the imbalances and injustices of the past, directly or indirectly affected the well-being of employees and consequently the organisation at large (Chipunza \& Gwarinda, 2010). This implies that changes can stimulate feelings of uncertainties about job security and in turn likely to influence individual employees' commitment towards their organisation.

Uncertainty can be described as the threat of job loss (Kinnunen, Mauno, Nätti, \& Happonen, 2000). For this study, the term uncertainty will be used synonymously with the term job insecurity. Hence, employees who experience uncertainty about future job security are likely to be insecure about whether they will be able to continue working, or will lose their jobs in the near future. Having said this, employees become uncertain about their jobs if they perceive the threat to their job to be dire and feel powerless to do anything about their situation (Moshoeu \& Geldenhuys, 2015).

Uncertainty has not received as much attention in the literature on organisational commitment (Lumingkewas, Nimran, Raharjo, \& Utami, 2019; Moshoeu \& Geldenhuys, 2015). Studies have shown that employees who perceive that they have an uncertain future in their jobs often feel threatened and anxious and may exhibit symptoms of distress such as depression (Lee, Huang, \& Ashford, 2018). Organisations, therefore, should minimise the uncertainties of job security among its employees. To minimise uncertainties in any organisation, management should constantly communicate the organisational strategic plan to its employees as well as assure them of job security, especially during difficult times such as what the higher education sector is currently facing (Bryson, 2018).

One can also argue that employment security is a vital aspect of employees' quality of life. For instance, Moshoeu and Geldenhuys (2015) establish that being employed gratifies several individual needs, such as earning income, and the need for personal and social growth. When these aspects are not met, uncertainties can affect the behaviour and emotional well-being of employees in an organisation (Khan, Soundararajan, Wood, \& Ahammad, 2017), leading to low organisational commitment (Clark, Knabe, \& Rätzel, 2010), particularly with high uncertainties created in the South African labour market. This study hypothesises that it is this uncertainty or insecurity that leads to the low level of employee organisational commitment among higher education academic staff. Therefore, the study investigates whether this is indeed the case. 


\section{Job satisfaction}

Despite various studies on the concept of job satisfaction, its meaning can differ based on particular contexts or theoretical positions. However, job satisfaction can, in general terms, be viewed as the extent to which individuals like their job and thus derive gratification from it (De Nobile, 2017; Spector, 2008; Valaei \& Rezaei, 2016). It has been conceptualised as how an individual feels about his or her job (George \& Zakkariya, 2018). There are various facets of job satisfaction, and these include the work itself, pay, promotion opportunities, supervision and co-workers (Matla \& Xaba, 2019).

Employee job satisfaction is deemed important aspects within the workplace. Mabasa and Ngirande (2015) state that job satisfaction increases employee organisational commitment and productivity. It is, therefore, vital to consider how employees in the organisation can be kept satisfied to achieve better results. Thus, job satisfaction is one of the important variables that contribute to the success of the organisation as a whole. The inverse relationship between occupational stress and job satisfaction has been strongly linked in various studies, including the education sector (Cheng, Liou, Tsai, \& Chang, 2015; Collie, Shapka, Perry, \& Martin, 2015; Courtney \& Phelan, 2019; Rana \& Soodan, 2019). Uncertainty about the future of one's job has also been found to be linked to low job satisfaction (Cheung, Wu, \& Ching Chi, 2019). Although studies on job satisfaction are reported previously (Cheng et al., 2015; Cheung et al., 2019; Collie et al., 2015; Courtney \& Phelan, 2019; Rana \& Soodan, 2019), studies that examined the moderating role of job satisfaction on the relationship between occupational stress, uncertainty and organisational commitment in higher education could not be found, hence the assumption that job satisfaction will moderate the relationship between occupational stress, uncertainty and organisational commitment of academic staff in the higher education sector.

\section{Organisational commitment}

Organisational commitment can be viewed as the psychological attachment that employees have with the organisation and its goals and the desire to stay with that particular organisation (Pieters, Van Zyl, \& Nel, 2019). Organisational commitment is characterised by three dimensions, namely continuance, normative and affective commitment (Meyer, Allen, \& Smith, 1993). Continuance commitment refers to one's commitment towards the organisation because of the costs associated with leaving it. Normative commitment is a result of one's desire to remain with the organisation because of perceived obligation. For instance, one can feel attached to an organisation because it has paid for their further studies. Affective commitment is the 'psychological and emotional attachment towards the organisation and working towards achieving the goals and objectives of the organisation' (Pieters et al., 2019, p. 2).

Various factors influence employee organisational commitment. These include occupational stress, uncertainty and job satisfaction (Haque, Aston, \& Kozlovski, 2018; Nelson, 2018; Tekingündüz, Top, Tengilimoğlu, \& Karabulut, 2017). For the institutions to remain productive and efficient, they need to make sure that their employees are committed and less stressed with their working environments. This is in line with Burke's (2017) view that employees who are highly stressed and uncertain about their future job security are likely to be less committed to their organisation.

Authorities in higher education institutions may need to understand the factors affecting the workforce's commitment. Higher education institutions should also understand the impact occupational stress and uncertainty have on employees' levels of organisational commitment, particularly when changes like a merger take place (Abildgaard, Nielsen, \& Sverke, 2018; Vosse \& Aliyu, 2018). In a similar view, Van der Westhuizen (2001) revealed that educators become more stressed and less committed when new educational policies are being introduced and new structures emerge as a result of interventions. The two institutions selected in this study were both affected by the higher education merger process. Therefore, it is important to explore the study variables.

\section{The relationship between occupational stress and organisational commitment}

Several studies have found a negative relationship between occupational stress and organisational commitment (Burke, 2017; Haque et al., 2018; Slade et al., 2016). These studies show that the more stressed an individual is, the less the likelihood that the individual will be committed to the organisation. However, a study by Faragher, Cass and Cooper (2013) and Arnolds et al. (2013) revealed that no relationship exists between occupational stress and organisational commitment.

\section{The relationship between uncertainty and organisational commitment}

A study by Lee et al. (2018) revealed that there is an inverse significant relationship between uncertainty and organisational commitment. In a similar view, Lumingkewas et al. (2019) pointed out that an employee experiencing high job uncertainty appears to have poor organisational commitment. This shows that as employees feel more uncertain about their jobs in the near future, they tend to be less committed to their organisation. In addition, Moshoeu et al.'s (2015) study on academic staff in an open distance learning institution revealed a negative significant relationship between uncertainty and organisational commitment.

\section{The moderating role of job satisfaction on the relationship between occupational stress, uncertainty and organisational commitment}

In the South African higher education context - historically black institutions - there is a paucity of literature on job satisfaction as a moderator of the relationship between occupational stress, uncertainty and organisational commitment. However, job satisfaction was found to be a 
predictor of occupational stress (Cheng et al., 2015; Rana \& Soodan, 2019), uncertainty (Cheung et al., 2019) and organisational commitment (Mabasa \& Ngirande, 2015). Hence, the assumption that job satisfaction moderates the relationship between occupational stress, uncertainty and organisational commitment.

Existing literature has shown that most studies that were conducted on the relationship between occupational stress, uncertainty and organisational commitment focussed mainly on different settings and on each variable separately (Cheung et al., 2019; Moshoeu \& Geldenhuys, 2015). Little is known about these relationships from the perspective of higher education. Besides, there is a dearth of knowledge on whether the relationship between occupational stress and uncertainty on organisational commitment is moderated by job satisfaction, hence the need to explore further.

Several studies have been conducted on the general effects of occupational stress, uncertainty and job satisfaction on employee organisational commitment (Cheng et al., 2015; Cheung et al., 2019; Lumingkewas et al., 2019; Rana \& Soodan, 2019). However, none of these studies investigated the relationship between occupational stress and uncertainty on organisational commitment together in the higher education sector. Furthermore, the researcher could not find information on the moderating role of job satisfaction on the relationship between occupational stress, uncertainty and organisational commitment. This made it necessary to explore the matter. Thus, this study investigates the relationship between occupational stress, uncertainty and organisational commitment and further explores whether job satisfaction moderates this relationship among higher education academic staff.

\section{Research purpose}

The main purpose of this study was to investigate the relationship between occupational stress, uncertainty and organisational commitment among academic staff in South African higher learning institutions. The study also explored whether job satisfaction moderates the relationship between occupational stress, uncertainty and organisational commitment. This study is important as it holds the potential to determine the proportion of variance in occupational stress and uncertainty on organisational commitment that is because of job satisfaction.

\section{Research objectives}

The objectives of the study are:

- To investigate the relationship between occupational stress and organisational commitment.

- To investigate the relationship between uncertainty and organisational commitment.
- To determine whether job satisfaction moderates the relationship between occupational stress and organisational commitment.

- To determine whether job satisfaction moderates the relationship between uncertainty and organisational commitment.

\section{Research hypotheses}

The study hypothesised that:

$\mathrm{H1}$ : There is a negative relationship between occupational stress and organisational commitment.

$\mathrm{H} 2$ : There is a negative relationship between uncertainty and organisational commitment.

H3: Job satisfaction moderates the relationship between occupational stress and organisational commitment.

H4: Job satisfaction moderates the relationship between uncertainty and organisational commitment.

\section{Conceptual model}

A conceptual model based on reviewed literature and the researchers' logical deductions as shown in Figure 1 was developed, and it shows the hypothesised moderating role of job satisfaction on the relationships between occupational stress, uncertainty and organisational commitment.

\section{Research methodology Research design}

A quantitative approach was used to gather data by using a cross-sectional research design. This was deemed appropriate in investigating the relationship between occupational stress, uncertainty, job satisfaction and organisational commitment and in testing research hypotheses (Creswell \& Creswell, 2017). Furthermore, as in Du Plooy-Cilliers, Davies and Bezuidenhout (2019), the quantitative approach was used in this study because the data were numerically and statistically presented.

\section{Research participants}

A sample of 424 academic staff, employed on a fixed-term, temporary contract from two rural-based higher education institutions - selected by using Raosoft sample size calculator online software - participated in the study. One institution is in the Limpopo Province, and the other one in Eastern Cape Province of South Africa. Both institutions share almost the same characteristics in terms of student

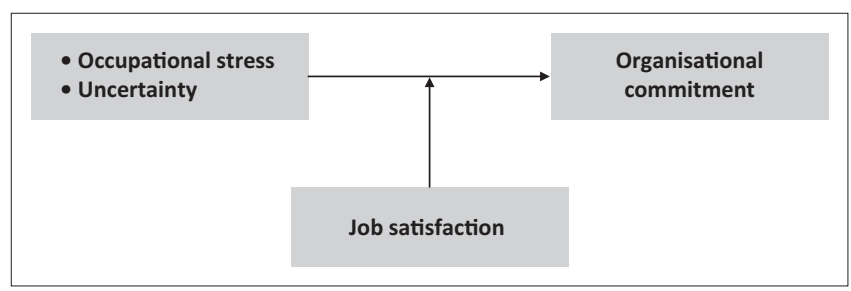

FIGURE 1: Theoretical moderating role of job satisfaction on occupational stress, uncertainty and organisational commitment. 
profile and are rural based. The characteristics of the respondents listed in Table 1 show that the overall sample had an equal number of males and females. The highest number of participants (45.8\%) were aged between 36 and 45 years, followed by the 46-55-year age group (37.7\%). The least number of the participants were those aged 25 years and below $(0.5 \%)$. Furthermore, the majority of the respondents had postgraduate degrees $(83 \%)$ and more than 10 years of working experience (63.2\%).

\section{Measuring instruments}

A self-administered questionnaire was used to collect data. The questionnaire consisted of biographical information and study variables such as occupational stress, uncertainty, job satisfaction and organisational commitment. The biographical information was collected by using a questionnaire developed by the researcher to get information regarding the respondents' gender, age, highest qualification and working experience from two institutions of higher learning. To measure occupational stress, a 16-item EffortReward Imbalance (ERI) questionnaire, composed of the effort and rewards subscale, was used. However, eight items were found to be good items (Tabachinick \& Fidell, 2013). The questionnaire previously established a coefficient alpha of 0.68 to 0.86 from five different groups of nursing home samples (Siegrist \& Peter, 1996). In the South African context, an alpha of 0.88 was found (Ngirande, 2019). Items that formed part of the scale include the following: 'I have constant pressure because of a heavy workload' and 'I receive the respect I deserve from my superiors'. Uncertainty regarding future job security was measured by using a 10-item questionnaire (De Witte, 2000), which asked the respondents to indicate their degree of certainty on whether they will have a job in the organisation in the near future. The questionnaire was rated on a 5-point rating scale ranging from 'strongly agree' (1) to 'strongly disagree' (5). Its previous alpha coefficient ranges between 0.76 and 0.96 (De Witte, 2000). In the South African context, Ngirande (2019) found an alpha of 0.77.

Job satisfaction was measured by using the 10-item Halpern's (1966) job satisfaction questionnaire. Examples of

\begin{tabular}{llcc} 
TABLE 1: Characteristics of the respondents $(n=424)$. & \\
\hline Variable & Category & Frequency & Percentage (\%) \\
\hline Gender & Male & 212 & 50.0 \\
& Female & 212 & 50.0 \\
Age category & 25 years and below & 2 & 0.5 \\
& 26-35 years & 34 & 8.0 \\
& 36-45 years & 194 & 45.8 \\
& 46-55 years & 160 & 37.7 \\
& 56 years and above & 34 & 8.0 \\
Highest qualification & Diploma & 4 & 0.9 \\
obtained & Undergraduate degree & 68 & 16.0 \\
& Postgraduate degree & 352 & 83.0 \\
Working experience & $<1$ year & 20 & 4.7 \\
in the organisation & 1-5 years & 50 & 11.8 \\
& 6-10 years & 86 & 20.3 \\
& 10 years and above & 268 & 63.2 \\
\hline
\end{tabular}

the items included in this scale are working conditions, opportunities for achievement, work itself and overall satisfaction. Organisational commitment was measured by using an 18-item organisational commitment questionnaire (Meyer \& Allen, 1997). This questionnaire has three subscales measuring normative commitment, affective commitment and continuance commitment, with six items on each subscale. However, the organisational commitment items were combined to form a single measure in this article, and 10 items were found to be good items for this study as well. Previous studies conducted in South Africa reported Cronbach's alphas ranging from 0.73 to 0.81 for the organisational commitment scale (Lumley, Coetzee, Tladinyane, \& Ferreira, 2011; Simons \& Buitendach, 2013). The whole questionnaire was measured on a 5-point rating scale ranging from 'strongly agree' (1) to 'strongly disagree' (5).

\section{Data processing and analysis}

The statistical package for social sciences (SPSS) version 26 was used to analyse data. Descriptive statistics were used to describe the sample profile. Several inferential, statistical techniques were conducted to analyse data in this study. Firstly, an item analysis was performed to inspect the internal consistency of variables under investigation. Secondly, confirmatory factor analysis (CFA) was also conducted to examine the construct validity of the measuring instruments. Correlation and multiple regression analyses were conducted to test the relationship between occupational stress, uncertainty and organisational commitment, and to check the predictor variable of organisational commitment respectively. Finally, to test the degree to which job satisfaction moderates the relationship between occupational stress, uncertainty and organisational commitment, hierarchical multiple regression analysis was conducted (Hayes, 2015).

\section{Descriptive statistics and reliability analysis}

Table 2 shows a summary of the key descriptive statistics of occupational stress, uncertainty, job satisfaction and organisational commitment scales by showing means and standard deviations (SDs). The normality of the data-set is also assessed by using skewness and kurtosis values. Cronbach's alphas are also displayed. The mean scores of the occupational stress, uncertainty, job satisfaction and organisational commitment were $3.3(\mathrm{SD}=6.33), 2.7$ $(\mathrm{SD}=2.5), 2.3(\mathrm{SD}=4.67), 2.5(\mathrm{SD}=10.5)$ and $2.3(\mathrm{SD}=10.30)$, respectively. Data were also normally distributed and allow

TABLE 2: Descriptive statistics and reliability statistics.

\begin{tabular}{lcccccc}
\hline Scale & $\boldsymbol{M}$ & SD & Skewness & Kurtosis & $\begin{array}{c}\text { Cronbach's } \\
\text { alpha }\end{array}$ & $\begin{array}{c}\text { No. } \\
\text { items }\end{array}$ \\
\hline Occupational stress & 3.3 & 6.330 & -0.881 & 0.431 & 0.767 & 8 \\
Uncertainty & 2.7 & 4.667 & 0.083 & -0.583 & 0.801 & 6 \\
Job satisfaction & 2.5 & 10.513 & 0.652 & -1.391 & 0.941 & 10 \\
$\begin{array}{l}\text { Organisational } \\
\text { commitment }\end{array}$ & 2.3 & 10.295 & 0.807 & -1.063 & 0.940 & 10 \\
\hline
\end{tabular}

SD, standard deviation. 
for further analysis as they range from -2 to 2 for both skewness and kurtosis (Tabachinick \& Fidell, 2013).

The reliability of the instruments was also shown by using Cronbach's alpha coefficients as depicted in Table 2. Items correlating below 0.30 with the total score were considered as poor items and were excluded from further analysis (Pallant, 2016). All four scales obtained good coefficient alphas, which range from 0.767 to 0.941 (Pallant, 2016). The highest reliabilities amongst the scales included job satisfaction $(\alpha=0.941)$ and organisational commitment ( $\alpha=0.940)$, followed by uncertainty $(\alpha=0.801)$ and occupational stress $(\alpha=0.767)$.

\section{Evaluating the fit of the measurement model}

Confirmatory factor analysis was carried out on all the scales utilised in the study to assess the goodness-of-fit of the measurement models by using AMOS version 26. Several fit indices were used to assess model fit. The results in Table 3 show an acceptable $p$-value of 0.000 (Hair, Black, Babin, \& Anderson, 2010). Diamantopoulos and Siguaw (2000) and Balogun, Mahembe and Allen-Ile (2020) pointed out that the standardised root mean square residual values below 0.05 are suggestive of good fit, those between 0.05 and under 0.08 suggest reasonable fit, values between 0.08 and 0.10 denote mediocre fit and values $>0.10$ indicate a poor fit. Results show a model misfit of standardised root mean square residual of 0.293 . The goodness of fit index, the comparative fit index, the incremental fit index and Tucker-Lewis index show the good fit category of 0.904, 0.941, 0.941 and 0.90 respectively (Hair et al., 2010). Likewise, the normed fit index (0.936) was also good. However, the relative fit index (0.888), the adjusted goodness of fit index (0.784) and Parsimony goodness fit index (0.402) slightly fail to meet a good model fit cut off point level of 0.90 .

The measurement model is shown in Figure 2.

\section{Validity and reliability of the measurement model}

According to Awang (2015), the assessment of modelling unidimensionality, validity and reliability for the measurement model is important before testing the relationships between

TABLE 3: Structural model fit summary.

\begin{tabular}{lc}
\hline Fit index & Indices \\
\hline$X^{2}$ & 199.022 \\
$p$ & 0.000 \\
Degrees of freedom & 16 \\
Standardised root mean square residual & 0.293 \\
Goodness of fit index & 0.904 \\
Comparative fit index & 0.941 \\
Incremental fit index & 0.941 \\
Tucker-Lewis index & 0.896 \\
Parsimony goodness fit index & 0.402 \\
Adjusted goodness of fit index & 0.784 \\
Normed fit index & 0.936 \\
Relative fit index & 0.888 \\
\hline
\end{tabular}

traits. In this article, the requirement of unidimensionality was met when the fitness indices reached the required level in the measurement model. Furthermore, all items obtained positive factor loadings. Consequently, after the CFA measurement model procedure, the validity and reliability of each construct was calculated. The composite reliability (CR) requirement was achieved as all $\mathrm{CR}$ values were $>0.60$ as shown in Table 4 (Awang, 2015; Byrne, 2016). The validity requirement was checked by assessing the convergent validity, construct validity and discriminant validity of the measurement model. To meet the requirements for convergent validity, all values of the average variance extracted (AVE) for each variable should be at least 0.5 (Rose, Awang, \& Yazid, 2017). As shown in Table 4, all values exceeded 0.5. In addition, the construct validity for the measurement model was also achieved when the fitness indices met the required level as shown in Table 3.

The diagonal values (in bold) is the square root of AVE of the construct, whereas other values are the correlation between the respective constructs. The discriminant validity for all constructs shown in Table 4 was achieved as the diagonal values (in bold) are higher than the values in its rows and columns.

\section{The relationship between occupational stress, uncertainty and organisational commitment}

Table 5 shows the Pearson product-moment correlation coefficients calculated to determine the strength of the relationship between occupational stress, uncertainty and organisational commitment. Hypothesis 1 stated that there is a significant relationship between occupational stress and organisational commitment. A negative significant relationship between occupational stress and organisational commitment (Table 5) was found ( $r=-0.311$; $p<0.01$ ). Hence, both hypotheses 1 and 2 were supported. A negative significant relationship between uncertainty and organisational commitment was also found $(r=-0.362$; $p<0.01)$. Furthermore, regression analyses were performed to determine whether the two independent variables (occupational stress and uncertainty) are significant predictors of organisational commitment.

TABLE 4: Validity and reliability.

\begin{tabular}{lccccccc}
\hline Variable & CR & AVE & MSV & $\mathbf{1}$ & $\mathbf{2}$ & $\mathbf{3}$ & $\mathbf{4}$ \\
\hline 1. Commitment & 0.972 & 0.946 & 0.973 & 0.972 & - & - & - \\
2. Uncertainty & 0.733 & 0.587 & 0.817 & $-0.440^{* * *}$ & 0.766 & - & - \\
$\begin{array}{l}\text { 3. Occupational } \\
\text { stress }\end{array}$ & 0.864 & 0.761 & 0.891 & $-0.352^{* * *}$ & $0.211^{* * *}$ & 0.872 & - \\
4. Job satisfaction & 0.936 & 0.880 & 0.957 & $0.912^{* * *}$ & $-0.458^{* * *}$ & $-0.325^{* * *}$ & 0.938 \\
\hline $\begin{array}{l}\text { CR, composite reliability; AVE, average variance extracted; Commitment, organisational } \\
\text { commitment; MSV, maximum shared variance. }\end{array}$ \\
$*, p<0.050 ; * *, p<0.010 ; * * *, p<0.001$.
\end{tabular}

TABLE 5: Pearson product-moment correlation coefficients.

\begin{tabular}{lccc}
\hline Variable & $\mathbf{1}$ & $\mathbf{2}$ & $\mathbf{3}$ \\
\hline 1. Occupational stress & - & - & - \\
2. Uncertainty & $0.173^{* *}$ & - & - \\
3. Organisational commitment & $-0.311^{* *}$ & $-0.362^{* *}$ & - \\
\hline ** Correlation is signicant at the 0.011 ( 1 (2-
\end{tabular}

**, Correlation is significant at the 0.01 level (2-tailed). 


\section{Occupational stress and uncertainty as predictors of organisational commitment}

Multiple regression analyses were performed to determine whether occupational stress and uncertainty can predict organisational commitment. In model 1, organisational commitment was used as the dependent variable, with occupational stress and uncertainty as independent variables. As shown in Table 6, entry of occupational stress and uncertainty at the first step of the regression analysis produced a statistically significant model $\left(F_{(3.420)}=50.885 ; p<0.01\right)$ and accounted for $19.5 \%$ of the variance. From the results, uncertainty $(\beta=-0.318$; $t=-7.162 ; p<0.01)$ is a significant predictor of organisational commitment. Occupational stress was also found to be a significant predictor of organisational commitment $(\beta=-0.256$; $t=-5.760 ; p<0.01$ ). Occupational stress was therefore, found to be the most significant predictor of employees' organisational commitment when compared to uncertainty.

\section{The moderating role of job satisfaction}

To test hypothesis 3 that states that job satisfaction moderates the relationship between occupational stress and organisational commitment, a two-stage, moderated, hierarchical multiple regression analysis was also performed (Baron \& Kenny, 1986). As displayed in Table 7, in the first step, two variables were included: occupational stress and job satisfaction. These variables accounted for a significant amount of variance in organisational commitment, $R^{2}=0.794, F_{(3,420)}=541.005, p=0.000$. To avoid potentially problematic high multicollinearity with the interaction term, the variables were also centred, and an interaction term between occupational stress and job satisfaction was created (Aiken \& West, 1991).

Next, the interaction term between occupational stress and job satisfaction was added to the regression model, which accounted for a significant proportion of the variance in organisational commitment, $\Delta R^{2}=0.002, \Delta F_{(1,420)}=4.503$, $\beta=-0.011, t_{(420)}=-2.122 p=0.0 .034$ as shown in Table 6. From these results, job satisfaction moderates the relationship between occupational stress and organisational commitment. Therefore, the hypothesis was supported.

From the slope analysis depicted in Figure 3, it can be interpreted that employees with high stress and low job satisfaction experience low level of organisational commitment. However, employees with high job satisfaction had higher levels of organisational commitment regardless of their level occupational stress.
To test hypothesis 4 that stated that job satisfaction moderates the relationship between uncertainty and organisational commitment, a two-stage, moderated, hierarchical multiple

TABLE 7: The moderating role of job satisfaction on the relationship between occupational stress and organisational commitment.

\begin{tabular}{lcccccccc}
\hline $\boldsymbol{( n = 4 2 4 )}$ & $\boldsymbol{R}^{2}$ & $\boldsymbol{\Delta \boldsymbol { R } ^ { 2 }}$ & $\boldsymbol{\beta}$ & $\boldsymbol{T}$ & $\boldsymbol{F}$ & $\boldsymbol{\Delta f}$ & $\boldsymbol{d f}$ & $\boldsymbol{p}$ \\
\hline Model 1 & & & & & & & & \\
OS, JS & 0.794 & - & - & - & 541.005 & - & 3.420 & 0.000 \\
Model 2 & & & & & & & & \\
OS*JS & - & 0.002 & -0.011 & -0.2 .122 & - & 4.503 & 1.420 & 0.034 \\
\hline
\end{tabular}

OS, occupational stress; JS, job satisfaction; OS*JS, interaction term; $R^{2}$, percentage variance explained; $\Delta R^{2}$, adjusted $R$ square; $\beta$, regression coefficient; $t$, test for independence mean; $F$, overall significance; $d f$, degrees of freedom; $p$, probability value.

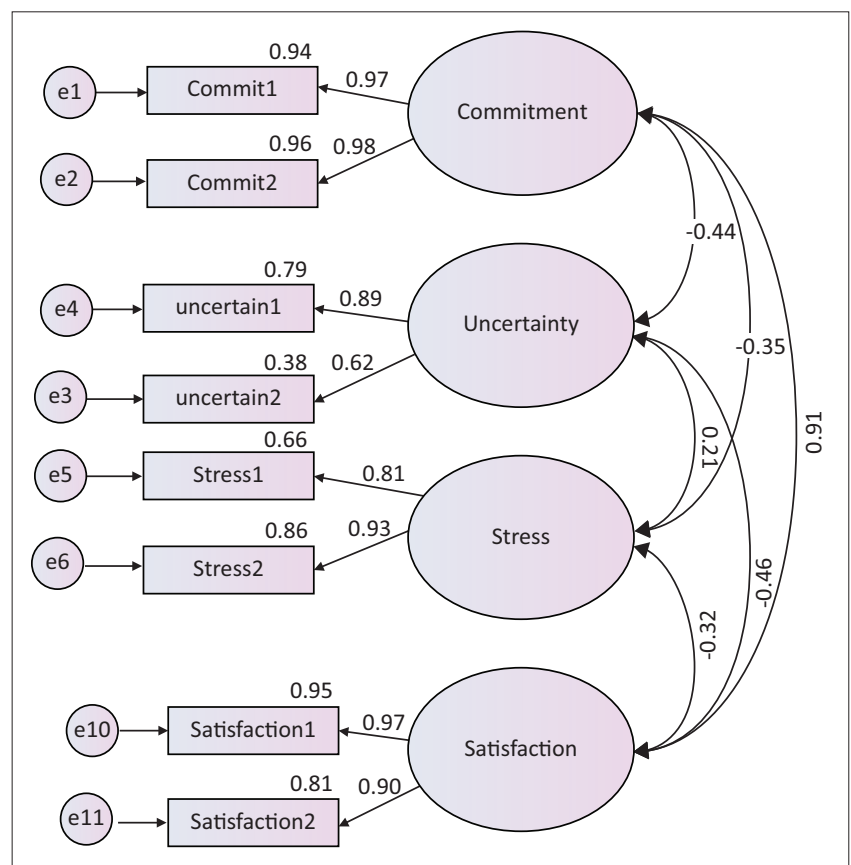

FIGURE 2: Measurement model.

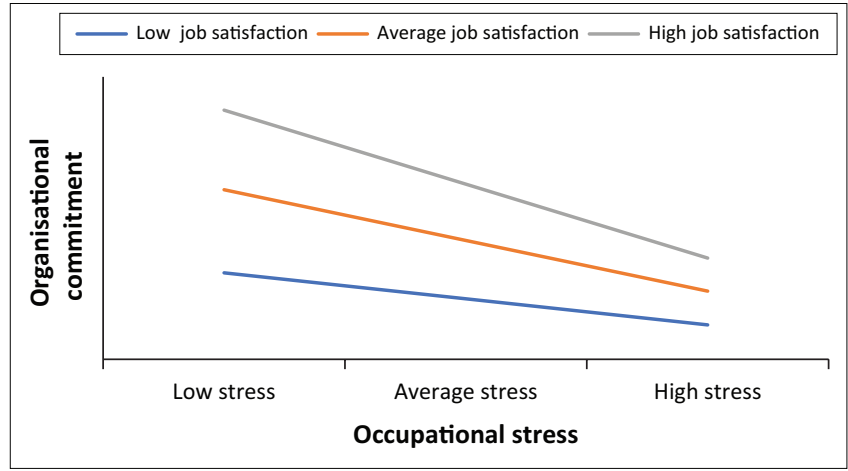

FIGURE 3: Testing the interaction effect of job satisfaction on the relationship between occupational stress and organisational commitment.

TABLE 6: Multiple regression with organisational commitment as the dependent variable and occupational stress and uncertainty as the independent variable.

\begin{tabular}{|c|c|c|c|c|c|c|c|}
\hline \multirow[t]{2}{*}{$\overline{\text { Model }}$} & \multicolumn{2}{|c|}{ Unstandardised coefficients } & \multirow{2}{*}{$\begin{array}{c}\text { Standardised coefficients } \\
(\beta)\end{array}$} & \multirow[t]{2}{*}{$t$} & \multirow[t]{2}{*}{$P$} & \multirow[t]{2}{*}{$F$} & \multirow[t]{2}{*}{$R^{2}$} \\
\hline & Beta & SE & & & & & \\
\hline (Constant) & 49.563 & 2.461 & - & 20.138 & 0.000 & 50.885 & 0.195 \\
\hline Uncertainty & -0.863 & 0.120 & -0.318 & -7.162 & $0.000 * *$ & - & - \\
\hline Occupational stress & -0.607 & 0.105 & -0.256 & -5.760 & $0.000 * *$ & - & - \\
\hline
\end{tabular}

$\mathrm{SE}$, standard error; $\beta$, regression coefficient; $t$, test; $p$, probability value; $F$, overall significance; $R^{2}$, percentage variance explained.

$* *, p \leq 0.01$. 
TABLE 8: The moderating role of job satisfaction on the relationship between uncertainty and organisational commitment.

\begin{tabular}{lccccccccc}
\hline $\boldsymbol{( n = 4 2 4 )}$ & $\boldsymbol{R}^{\mathbf{2}}$ & $\Delta \boldsymbol{R}^{\mathbf{2}}$ & $\boldsymbol{\beta}$ & $\mathbf{T}$ & $\boldsymbol{F}$ & $\Delta \boldsymbol{F}$ & $\boldsymbol{d f}$ & $\boldsymbol{p}$ \\
\hline Model 1 & & & & & & & & \\
Uncert, JS & 0.793 & - & - & - & 537.758 & - & 3.420 & 0.000 \\
Model 2 & & & & & & & & \\
Uncert*JS & - & 0.006 & -0.020 & -3.419 & - & 11.691 & 1.420 & 0.034 \\
\hline
\end{tabular}

Uncert, Uncertainty; JS, job satisfaction; Uncert*JS, interaction term; $R^{2}$, percentage variance explained; $\Delta R^{2}$, adjusted $R$ square; $\beta$, regression coefficient; $t$, test for independence mean $F$, overall significance; $d f$, degrees of freedom; $p$, probability value.

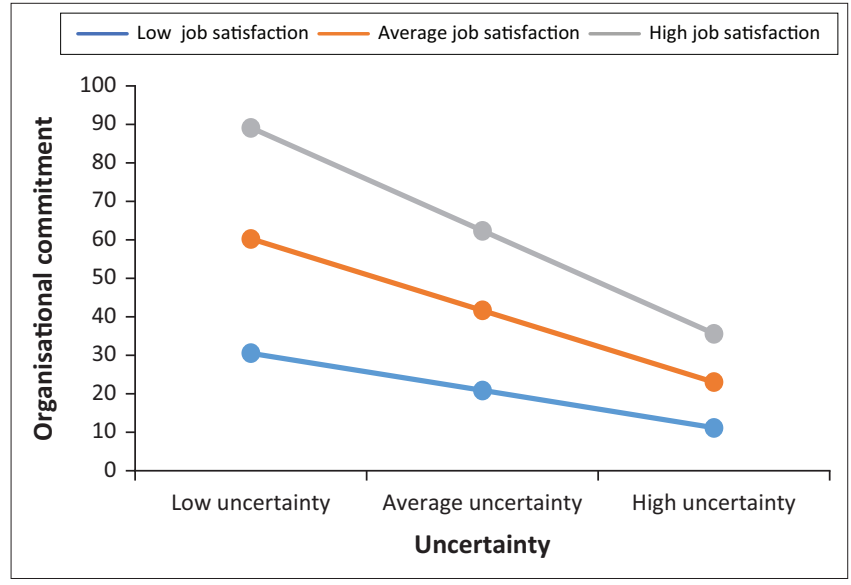

FIGURE 4: Testing the interaction effect of job satisfaction on the relationship between uncertainty and organisational commitment.

regression analysis was performed (Baron \& Kenny, 1986). In the first step, two variables were included: uncertainty and job satisfaction. These variables accounted for a significant amount of variance in organisational commitment, $R^{2}=0.793$, $F_{(3,420)}=537.758, p<0.001$ (Table 8). To avoid potentially problematic high multicollinearity with the interaction term, the variables were centered, and an interaction term between uncertainty and job satisfaction was created (Aiken \& West, 1991; Pu, Hou, Ma, \& Sang, 2017).

Next, the interaction term between uncertainty and job satisfaction was added to the regression model, which accounted for a significant proportion of the variance in organisational commitment, $\Delta R^{2}=0.006, \Delta F_{(1,420)}=11.691$, $\beta=-0.020, t_{(420)}=-3.419, p<0.05$ (Table 8). Job satisfaction, therefore, moderates the relationship between uncertainty and organisational commitment. Hence, hypothesis 4 was supported.

From the slope analysis depicted in Figure 4, it can be interpreted that employees' level of organisational commitment is at its highest when there is high job satisfaction and low uncertainty. It was also noted that employees' level of organisational commitment was at its lowest when there was high uncertainty and low job satisfaction.

\section{Discussion}

The purpose of the study was to determine the relationship between occupational stress, uncertainty and organisational commitment among academic staff in South African higher learning institutions and to determine whether job satisfaction moderates the relationship between occupational stress, uncertainty and organisational commitment among academic staff. An equal number of males and females participated in the study, with the highest number of participants in the middle age group of between 36 and 45 years old. As expected of academics, the majority of the respondents had a postgraduate degree with more than 10 years' working experience in the higher education sector.

\section{Reliability and validity of instruments}

High levels of internal consistency reliabilities for the measuring instruments used in this study were found. All four scales obtained acceptable Cronbach's alpha coefficients $(\alpha)$ according to the guideline of $\alpha \geq 0.70$ (Pallant, 2016). The highest reliabilities amongst the scales included job satisfaction $(\alpha=0.941)$, organisational commitment ( $\alpha=0.940)$, uncertainty $(\alpha=0.801)$ and occupational stress ( $\alpha=0.767$ ). Confirmatory factor analysis used to test whether the observed data correlate with the variables based on the form defined in a measurement model through creating classified-fit indices (Kline, 2016) shows that model fits the data. The construct validity was achieved as all model fit indices were greater than 0.05 (Jöreskog \& Sörbom, 1996). The results also show that all constructs are well measured by their indicators as the average variance explained was $>0.05$. Convergent validity and discriminant validity was therefore achieved (see Rose et al., 2017).

\section{The relationship between occupational stress, uncertainty and organisational commitment}

The study used Pearson product-moment correlation coefficients to assess the relationship between occupation stress, uncertainty and organisational commitment. The results confirm the first hypothesis of the study that there is a negative significant relationship between occupational stress and organisational commitment. The results show that occupational stress has an inverse relationship with organisational commitment. Likewise, several studies confirm that highly stressed employees are more likely to be less committed to their organisations (Burke, 2017; Haque et al., 2018; Slade et al., 2016). However, Arnolds et al.'s (2013) study revealed that there is no relationship between occupational stress and organisational commitment. From the findings, one can argue that occupational stress can be an antecedent of organisational commitment and a significant predictor of organisational commitment. This might be explained by the rapid changes in higher education, which can make the academic staff to become less committed to their organisation because of high pressures in the working environment.

A negative significant relationship between uncertainty and organisational commitment was also found. This finding confirms hypothesis 2 that states that as employees become more uncertain about their future job security, their level of organisational commitment decreases as well. Previous studies confirm the finding that a negative relationship between uncertainty and organisational 
commitment exists (Lee et al., 2018; Lumingkewas et al., 2019). Moshoeu and Geldenhuy's (2015) study of staff in higher education also revealed the same result. This shows that as employees feel unsure about their jobs, they tend to be less committed to their organisation. The regression analysis also confirms that both uncertainty and job stress are predictors of organisational commitment. Slade et al. (2016) support the results of the current study that uncertainty and occupational stress have a significant predictive value to organisational commitment. Khan et al. (2017) echoed the same sentiments by pointing out that when employees perceive their job as uncertain, they are more likely to become less attached to the organisation. Therefore, these results are important as employee behaviour is determined by various organisational aspects, and they should be explored. This will assist organisations to make well-informed policies that will promote high employee commitment.

\section{Job satisfaction as moderator of occupational stress and organisational commitment, as well as the relationship between uncertainty and organisational commitment}

The findings of the study confirm hypothesis 3 that states that job satisfaction moderates the relationship between occupational stress and organisational commitment. The results indicated that stressed employees will experience less commitment. However, this relationship can be explained by job satisfaction. Therefore, job satisfaction does moderate the relationship between occupational stress and organisational commitment. Job satisfaction was also found to be a moderator of the relationship between uncertainty and organisational commitment among academic staff in higher education. Therefore, the results confirmed hypothesis 4 that states that job satisfaction moderates the relationship between uncertainty and organisational commitment.

These findings brought new insight into the body of knowledge as there is a dearth of knowledge about the intervening role of job satisfaction on the relationship between occupational stress, uncertainty and organisational commitment in general, and in higher education in particular. Organisations can use the study findings to develop interventions and strategies that promote employee organisational commitment.

\section{Limitations}

Whilst this study explored work-related issues such as occupational stress, uncertainty and job satisfaction, and the effect thereof on organisational commitment for individuals and organisations, it had some limitations. The population of higher education institutions is too small to generalise the findings to the larger population. A cross-sectional sample was employed, which may result in employees overthinking their responses on items in the scales. Relatively little research has been conducted on the moderating role of job satisfaction on the relationship between occupational stress, uncertainty and organisational commitment in South African higher education, which makes it difficult to relate the findings to the South African context.

\section{Recommendations for future research}

It is recommended that future studies make use of a longitudinal design to examine the relationship between the variables of the study. Future research can address the limitations of the generalisation of the study results by using a larger sample size of higher education institutions. In this study, the moderating role of job satisfaction on the relationship between occupational stress, uncertainty and organisational commitment was investigated, and insignificant results were found on the moderating role of job satisfaction on the relationship between occupational stress and organisational commitment. Further studies can investigate the mediating role of job satisfaction in these relationships to gain more insight into employee attitudes and behaviour.

\section{Implications}

In practical terms, the new knowledge gained from observing the relationship between occupational stress, uncertainty and organisational commitment may be useful in the retention and promotion of organisational commitment of employees in the higher education sector. The results suggest that to have employees who identify themselves attached to their respective organisations, managers need to review existing policies and practices to lessen job stress and job uncertainties and promote positive attitude and behaviour among employees.

\section{Conclusion}

The relationship between occupational stress, uncertainty and job satisfaction on organisational commitment can be viewed as valuable to managers in enabling them to develop workplace strategies that minimise occupational stress, uncertainty and increase job satisfaction and to contribute towards improving positive workplace outcomes such as organisational commitment.

It is evident that less occupational stress and uncertainty lead to more committed employees. Occupational stress, uncertainty and organisational commitment need further investigation in employees within the South African higher education to explicitly understand how they relate to each other, and how an understanding of these phenomena can contribute to employees' organisational commitment.

\section{Acknowledgements Competing interests}

The author declares that no financial or personal relationships that may have inappropriately influenced him in writing this article. 


\section{Author's contributions}

H.N. is the sole author of this article.

\section{Ethical consideration}

This article followed all ethical standards for carrying out research without direct contact with human or animal subjects.

\section{Funding information}

This research received no specific grant from any funding agency in the public, commercial or not-for-profit sectors.

\section{Data availability statement}

Data sharing is not applicable to this article as no new data were created or analysed in this study.

\section{Disclaimer}

The views and opinions expressed in this article are those of the author and do not necessarily reflect the official policy or position of any affiliated agency of the author.

\section{References}

Abildgaard, J.S., Nielsen, K., \& Sverke, M. (2018). Can job insecurity be managed? Evaluating an organisational-level intervention addressing the negative effects of restructuring. Work \& Stress, 32(2), 105-123. https://doi.org/10.1080/02678373. restructuring. Wor

Aiken, L.S., \& West, S.G. (1991). Multiple regression: Testing and interpreting interactions. Thousand Oaks, CA: Sage.

Akalu, G.A. (2016). Higher education 'massification' and challenges to the professoriate: Do academics' conceptions of quality matter? Quality in Higher Education, 22(3), 260-276. https://doi.org/10.1080/13538322.2016.1266230

Arnolds, C.A., Lillah, R., \& Stofile, R.N. (2013). Assessing the outcomes of the higher education mergers in South Africa: Implications for strategic management. Acto Commercii, 13(1), 1-11.

Awang, Z. (2015). SEM made simple: A gentle approach to learning structural equation modelling. Bandar Baru Bangi: MPWS Rich Resources.

Badat, S. (2010). The challenges of transformation in higher education and training institutions in South Africa. Development Bank of Southern Africa, 8, 1-37.

Balogun, T.V., Mahembe, B., \& Allen-lle, C. (2020). A confirmatory factor analytic study of an authentic leadership measure in Nigeria. SA Journal of Human Resource Management/SA Tydskrif vir Menslikehulpbronbestuur, 18(0), a1235. https://doi. org/10.4102/sajhrm.v18i0.1235

Baron, R.M., \& Kenny, D.A. (1986). The moderator-mediator variable distinction in social psychological research: Conceptual, strategic, and statistical considerations. social psychological research: Conceptual, strategic, and st
Journal of Personality and Social Psychology, 51(6), 1173.

Boughey, C. (2005). 'Epistemological' access to the university: An alternative perspective. South African Journal of Higher Education, 19(3), 230-242. https:// doi.org/10.4314/sajhe.v19i3.25516

Boyd, C.M., Tuckey, M.R., \& Winefield, A.H. (2014). Perceived effects of organisational downsizing and staff cut on the stress experience: The role of resources. Stress and Health, 30(1), 53-64.

Bozzoli, B. (2016, July 14). Top South African university says it is 'financially vulnerable' Business tech. Retrieved from https://businesstech.co.za/news/finance/130160/ top-south-african-university-says-it-is-financially-vulnerable/

Bryson, J.M. (2018). Strategic planning for public and non-profit organisations: A guide to strengthening and sustaining organisational achievement. Twin Cities: John Wiley \& Sons.

Burke, W. W. (2017). Organization change: Theory and practice. Washington: Sage Publications.

Byrne, B.M. (2016). Structural equation modeling with Amos: Basic concepts, applications, and programming (3rd edn.). New York, NY: Routledge.

Cheng, C.Y., Liou, S.R., Tsai, H.N., \& Chang, C.H. (2015). Job stress and job satisfaction among new graduate nurses during the first year of employment in Taiwan. International Journal of Nursing Practice, 21(1), 410-418. https://doi. org/10.1111/ijn.12281

Cheung, F.Y.L., Wu, A.M., \& Ching Chi, L. (2019). Effect of job insecurity, anxiety and personal resources on job satisfaction among casino employees in Macau: A moderated mediation analysis. Journal of Hospitality Marketing \& Management 28(3), 379-396.
Chipunza, C., \& Gwarinda, S.A. (2010). 'Transformational leadership in merging higher education institutions: a case study. SA Journal of Human Resources Management, 8(1), 1-10. https://doi.org/10.4102/sajhrm.v8i1.195

Clark, A.E., Knabe, A., \& Rätzel, S. (2010). 'Boon or bane? Others' unemployment, wellbeing and job insecurity', Labour Economics, 17(1), 52-61.

Collie, R.J., Shapka, J.D., Perry, N.E., \& Martin, A.J. (2015). Teachers' beliefs about social-emotional learning: Identifying teacher profiles and their relations with job stress and satisfaction. Learning and Instruction, 39(1), 148-157. https://doi. org/10.1016/j.learninstruc.2015.06.002

Cooper, C.L. (ed.). (2018). Managerial, occupational and organisational stress research. New York, NY: Routledge.

Council on Higher Education (CHE). (2013). A proposal for undergraduate curriculum reform in South Africa: The case for a flexible curriculum structure. Pretoria: reform in South Africa: The
Council on Higher Education.

Courtney, J., \& Phelan, M. (2019). Translators' experiences of occupational stress and job satisfaction. Translation \& Interpreting, 11(1), 100-113. https://doi. org/10.12807/ti.111201.2019.a06

Creswell, J.W., \& Creswell, J.D. (2017). Research design: Qualitative, quantitative, and mixed methods approach. London: Sage.

Department of Education. (1997). A programme for the transformation of higher education, Education White Paper 3. Pretoria: Government Printers.

De Nobile, J. (2017). Organisational communication and its relationships with job satisfaction and organisational commitment of primary school staff in Western Australia. Educational Psychology, 37(3), 380-398. https://doi.org/10.1080/0144 3410.2016.1165797

De Oliveira Barbosa, M.L., Pires, A., \& Dwyer, T. (2018). Higher education, development, and inequality in Brazil and South Africa. Changing Societies \& Personalities, 2(4), 366-392.

De Witte, H. (2000). Work ethic and job insecurity: Assessment and consequences for well-being, satisfaction and performance at work. From Group to Community, 52, 325-350.

Diamantopoulos, A., Siguaw, J. A., \& Siguaw, J. A. (2000). Introducing LISREL: A guide for the uninitiated. Sage Publications.

Du Plooy-Cilliers, F., Davis, C., \& Bezuidenhout, R.M. (2019). Research matters. Cape Town: Juta.

Faragher, E.B., Cass, M., \& Cooper, C.L. (2013). The relationship between job satisfaction and health: a meta-analysis. In From stress to wellbeing Volume 1 (pp. 254-271). London: Palgrave Macmillan.

George, E., \& Zakkariya, K.A. (2018). Job satisfaction and job-related stress. In Psychological empowerment and job satisfaction in the banking sector (pp. 87-126). London: Palgrave Pivot, Cham.

Graebner, M.E., Heimeriks, K.H., Huy, Q.N., \& Vaara, E. (2017). The process of postmerger integration: A review and agenda for future research. Academy of Management Annals, 11(1), 1-32. https://doi.org/10.5465/annals.2014.0078

Halpern, G. (1966). Relative contributions of motivator and hygiene factors to overall job satisfaction. Journal of Applied Psychology, 50(3), 198-200.

Hair, J.F., Black, W.C., Babin, B.J., \& Anderson, R.E. (2010). Multivariate data analysis: International version. New Jersey: Pearson.

Haque, A.U, Aston, J., \& Kozlovski, E. (2018). The impact of stressors on organisational commitment of managerial and non-managerial personnel in contrasting economies: Evidence from Canada and Pakistan. International Journal of Business, 23(2), 166-182.

Hayes, A. F. (2015). An index and test of linear moderated mediation. Multivariate behavioural research, 50(1), 1-22.

Herman, P. (2016, August 26). 16 SA universities in 'financial distress' named. Cape Town: News24. Retrieved from https://www.news24.com/SouthAfrica/News/16 Town: News24. Retrieved from https://www.news24.
sa-universities-in-financial-distress-named-20160826

Jöreskog, K.G., \& Sörbom, D. (1996). LISREL 8 user's reference guide. Chicago, IL: Scientific Software.

Khan, Z., Soundararajan, V., Wood, G., \& Ahammad, M. F. (2020). Employee emotional resilience during post-merger integration across national boundaries: Rewards and the mediating role of fairness norms. Journal of World Business, 55(2), 1-11.

Kinnunen, U., Mauno, S., Nätti, J., \& Happonen, M. (2000). Organisational antecedents and outcomes of job insecurity: A longitudinal study in three organisations in Finland. Journal of Organisational Behaviour, 21(4), 443-459. https://doi. org/10.1002/(SICI)1099-1379(200006)21:4<443::AID-JOB24>3.0.CO;2-N

Kline, R. B. (2016). Principles and practices of structural equation modelling (4th edn.) New York: Guilford Press.

Lee, C., Huang, G.H., \& Ashford, S.J. (2018). Job insecurity and the changing workplace: Recent developments and future trends in job insecurity research. Annual Review of Organisational Psychology and Organisational Behaviour, 5, 335-359.

Lumingkewas, C.S., Nimran, U., Raharjo, K., \& Utami, H.N. (2019). Effect of job insecurity to organisational commitment and intention to leave. WACANA, Jurnal Sosial dan Humaniora, 22(4), 256-260.

Lumley, E.J., Coetzee, M., Tladinyane, R., \& Ferreira, N. (2011). Exploring the job satisfaction and organisational commitment of employees in the information technology environment. Southern African Business Review, 15(1), 100-118.

Mabasa, F.D., \& Ngirande, H. (2015). Perceived organisational support influences on job satisfaction and organisational commitment among junior academic staf members. Journal of Psychology in Africa, 25(4), 364-366. https://doi.org/10.108 $0 / 14330237.2015 .1078102$

Machingambi, S. (2011). Is access to higher education a sufficient condition for social equity in South Africa? A critical analysis. Journal of Social Sciences, 28(1), $13-20$. 
Martin, A., \& Roodt, G. (2008). Perceptions of organisational commitment, job satisfaction and turnover intentions in a post-merger South African tertiary institution. SA Journal of Industrial Psychology, 34(1), 23-31. https://doi. institution. SA Journal of

Matla, S.J., \& Xaba, M.I. (2019). Teachers' job satisfaction at well-performing, historically disadvantaged schools. International Journal of Educational Management, 34(4), 725-736. https://doi.org/10.1108/JJEM-08-2019-0303

Mckenna, S. (2012). The context of access and foundation provisioning in South Africa. In R. Dhunpath (Ed.), Alternative access to higher education: Underprepared students or underprepared institutions (pp. 51-61). Cape Town: Pearson Education South Africa.

Meyer, J.P., \& Allen, N.J. (1997). Commitment in the workplace: Theory, research, and application. Thousand Oaks, CA: Sage.

Meyer, J.P., Allen, N.J., \& Smith, C. (1993). Commitment to organisations and occupations: Extension and test of a three-component model conceptualization. Journal of Applied Psychology, 78(4), 538-551. https://doi.org/10.1037/0021 9010.78.4.538

Mohamedbhai, G. (2014). Massification in higher education institutions in Africa: Causes, consequences and responses. International Journal of African Higher Education, 1(1), 59-83.

Moshoeu, A.N., \& Geldenhuys, D.J. (2015). Job insecurity, organisational commitmen and work engagement among staff in an open distance learning institution. Southern African Business Review, 19(1), 22-43. https://doi.org/10.25159/1998$8125 / 5832$

Nelson, A. (2018). Uncertainty amidst change: The impact of privatisation on employee job satisfaction. Managerial, Occupational and Organisational Stress Research, 68, 345 .

Ngirande, H. (2019). Job satisfaction, organisational commitment, occupational stress and the moderating effect of uncertainty in merged and unmerged institutions in South Africa. Doctoral thesis. Eastern Cape: University of Fort Hare.

Nortje, N. (2013, May 28). The great debate- permanent employee or contract? Johannesburg: INTUATE Group.

Öztürk, E.B., Karagonlar, G., \& Emirza, S. (2017). Relationship between job insecurity and emotional exhaustion: Moderating effects of prevention focus and affective organisational commitment. International Journal of Stress Management, 24(3), 247. https://doi.org/10.1037/str0000037

Pallant, J. (2016). SPSS survival manual: A step by step guide to data analysis using SPSS (6th edn.). London: McGraw-Hill.

Pieters, W.R., Van Zyl, E., \& Nel, P. (2019). Job attitudes as a predictor of work engagement of the lecturing staff at the University of Namibia. SA Journal of Human Resource Management, 17, 11.
Pu, J., Hou, H., Ma, R., \& Sang, J. (2017). The effect of psychological capital between work-family conflict and job burnout in Chinese university teachers: Testing for mediation and moderation. Journal of Health Psychology, 22(14), 1799-1807. https://doi.org/10.1177/1359105316636950

Rana, A., \& Soodan, V. (2019). Effect of occupational and personal stress on job satisfaction, burnout, and health: A cross-sectional analysis of college teachers in Punjab, India. Indian Journal of Occupational and Environmental Medicine, 23(3), 133.

Rose, I., Awang, Z., \& Yazid, S. (2017). Inflight service quality of Malaysia Airlines: Validation using SEM and AMOS. International Journal of Academic Research in Business and Social Sciences, 7(10), 478-497.

Siegrist, J., \& Peter, R. (1996). Threat to occupational status control and cardiovascular risk. Israel Journal of Medical Sciences, 32(3-4), 179-184.

Simons, J.C., \& Buitendach, J.H. (2013). Psychological capital, work engagement and organisational commitment amongst call centre employees in South Africa. SA Journal of Industrial Psychology, 39(2), 1-12. https://doi.org/10.4102/sajip v39i2.1071

Slade, C.P., Ribando, S.J., \& Fortner, C.K. (2016). Faculty research following a merger: A job stress and social identity theory perspective. Scientometrics, 107(1), 71-89.

Smit, R. (2012). Towards a clearer understanding of student disadvantage in higher education: Problematising deficit thinking. Higher Education Research \& Development, 31(3), 369-380. https://doi.org/10.1080/07294360.2011.634383

Spector, P.E. (2008). Industrial and organisational psychology (5th edn.). Hoboken, NJ: John Wiley \& Sons.

Tabachinick, B.G., \& Fidell, L.S. (2013). Using multivariate statistics (6th edn). Boston, MA: Pearson Education.

Tekingündüz, S., Top, M., Tengilimoğlu, D., \& Karabulut, E. (2017). Effect of organisational trust, job satisfaction, individual variables on the organisational commitment in healthcare services. Total Quality Management \& Business Excellence, 28(5-6), 522-541.

Valaei, N., \& Rezaei, S. (2016). Job satisfaction and organisational commitment. Management Research Review, 39(12), 1663-1694. https://doi.org/10.1108/ MRR-09-2015-0216

Van der Westhuizen, P.C. (2001). Effective educational management. Pretoria: HAUM: Kagiso.

Vosse, B.J.F., \& Aliyu, O.A. (2018). Determinants of employee trust during organisational change in higher institutions. Journal of Organisational Change Management, 31(5), 1105-1118. https://doi.org/10.1108/JOCM-05-2017-0203

Zagelmeyer, S., Sinkovics, R.R., Sinkovics, N., \& Kusstatscher, V. (2018). Exploring the link between management communication and emotions in mergers and acquisitions. Canadian Journal of Administrative Sciences, 35(1), 93-106. https:// doi.org/10.1002/cjas.1382 